\title{
Ethylene and expansin biosynthesis related genes polymorphism in local apple (Malus domestica Borkh.) cultivars from VIR Collection of plant genetic resources
}

\author{
I.N. Shamshin ${ }^{1} \otimes$, A.V. Shlyavas ${ }^{2}$, A.A. Trifonova ${ }^{3}$, K.V. Boris ${ }^{3}$, A.M. Kudryavtsev ${ }^{3}$ \\ ${ }^{1}$ Michurinsk State Agrarian University, Michurinsk, Russia \\ ${ }^{2}$ Federal Research Center the N.I. Vavilov All-Russian Institute of Plant Genetic Resources (VIR), St. Petersburg, Russia \\ 3 Vavilov Institute of General Genetics, RAS, Moscow, Russia
}

\begin{abstract}
At Pushkin and Pavlovsk Laboratories of the N.I. Vavilov All-Russian Institute of Plant Genetic Resources (VIR) a diverse collection of local apple cultivars is maintained. Some of the cultivars are widely used in breeding programs for their ecological plasticity, increased adaptation to abiotic stress and disease resistance, still there have been no large-scale studies of these local cultivars for fruit storage ability. Fruit softening during storage is an important problem for apple production. Retention of desirable firmness after prolonged storage is one of the key requirements for new apple cultivars. Expansin and ethylene biosynthesis related genes are known to be involved in control of fruit softening in apple, and gene specific molecular markers have been reported. In this study the polymorphism and allelic configuration of ethylene and expansin biosynthesis related genes $M d-A C S 1, M d-A C O 1$ and Md-Exp7 involved in control of fruit softening in 87 local apple cultivars from VIR Collection of Plant Genetic Resources were analyzed. PCR markers Md-ACS1, Md-ACO1 and SSR-marker Md-Exp7 were used in the study. The allele frequencies in the collection generally coincided with the data from previous studies. Md-ACS1 allele 2 associated with reduced ethylene production was found only in three local cultivars, while all the studied local cultivars were heterozygous for the Md-ACO1 locus, as well as most modern Russian apple cultivars. Half of the studied local cultivars were heterozygous for Md-Exp7 (198:202). Thirteen local cultivars with rare Md-Exp7 alleles (206, 210 and 212) were detected. No association was found between the Md-Exp7 genotype and the cultivars' maturation time. The obtained results can be used for additional evaluation of the cultivars' potential for breeding.
\end{abstract}

Key words: apple; local cultivars; ethylene production; expansin; fruit softening; marker assisted breeding.
HOW TO CITE THIS ARTICLE:

Shamshin I.N., Shlyavas A.V., Trifonova A.A., Boris K.V., Kudryavtsev A.M. Ethylene and expansin biosynthesis related genes polymorphism in local apple (Malus domestica Borkh.) cultivars from VIR Collection of plant genetic resources. Vavilovskii Zhurnal Genetiki i Selektsii = Vavilov Journal of Genetics and Breeding. 2018;22(6):660-666. DOI 10.18699/VJ18.408

\section{Полиморфизм генов биосинтеза этилена и экспансина у местных и стародавних сортов яблони (Malus domestica Borkh.) из коллекции генетических ресурсов растений ВИР}

\author{
И.Н. Шамшин ${ }^{1} \otimes$, А.В. Шиявас ${ }^{2}$, А.А. Трифонова ${ }^{3}$, К.В. Борис ${ }^{3}$, \\ А.М. КуАрявцев ${ }^{3}$

\footnotetext{
${ }^{1}$ Мичуринский государственный аграрный университет, Мичуринск, Россия

2 Федеральный исследовательский центр Всероссийский институт генетических ресурсов растений им. Н.И. Вавилова (ВИР), Санкт-Петербург, Россия

${ }^{3}$ Институт общей генетики им. Н.И. Вавилова Российской академии наук, Москва, Россия
}

В Пушкинских и Павловских лабораториях Всероссийского института генетических ресурсов растений им. Н.И. Вавилова (ВИР) представлена коллекция разнообразных местных и стародавних сортов яблони. Некоторые из них широко используются в селекционных программах благодаря экологической пластичности, повышенной устойчивости к абиотическому стрессу и болезням, однако масштабных исследований лежкости плодов у местных и стародавних сортов не проводилось. Лежкость плодов является важной проблемой для производителей. Сохранение твердости плодов во время длительного хранения - одно из ключевых требований, предъявляемых к новым сортам яблони. Показано, что гены биосинтеза этилена и экспансина вовлечены в контроль лежкости у яблони, разработаны специфичные молекулярные маркеры для этих генов. В настоящем исследовании проведен анализ аллельного разнообразия генов биосинтеза этилена и экспансина Md-ACS1, Md-ACO1 и Md-Exp7, вовлеченных в контроль лежкости плодов у 87 местных и стародавних сортов яблони из коллекции генетических ресурсов растений ВИР. Были использованы ПЦР-маркеры Md-ACS1, Md-ACO1 и SSR-маркер Md-Exp7. Частоты аллелей в изученной коллекции в целом совпадали с данными предыдущих исследований. Аллель 2 гена Md-ACS1, определяющий сниженный уровень синтеза этилена, был выявлен только у трех образцов, в то время как все изученные местные и стародавние сорта были гетерозиготны по локусу Md-ACO1, так же как и большинство изученных ранее современных отечественных сортов яблони. Половина проанализированных образцов были гетерозиготны по локусу Md-Exр7 (198:202). Выявлено 13 местных и стародавних сортов, несущих редкие аллели гена Md-Exp7 (206, 210 и 212). Не было обнаружено связи между сочетанием аллелей гена $M d$-Exp7 и временем созревания изученных сортов. Полученные результаты могут быть использованы при дополнительной оценке потенциала изученных генотипов яблони для селекции.

Ключевые слова: яблоня; местные и стародавние сорта; синтез этилена; экспансин; лежкость плодов; маркер-ассоциированная селекция. 
A pple is a climacteric fruit that needs special postharvest handling to provide year-round high-quality apples to consumers. Shelf life - one of the key characteristics of apple cultivars - is limited by loss of firmness during storage and transportation, known as fruit softening. Shelf life depends not only on growing methods, harvesting time and successful application of postharvest technologies but also on the genetic basis of a cultivar. Firmness at harvest and after storage varies greatly among apple cultivars (Bratilova et al., 2015). Retention of desirable firmness after prolonged storage is one of the key requirements for new cultivars. Apple genotypes with prolonged storage time have always been of great interest to breeders, and DNA markers are widely used to study the genetic potential of Malus germplasm for breeding purposes. Today, in studies of fruit softening in Russian and international apple germplasm collections, ethylene and expansin biosynthesis related genes markers are widely used (Nybom et al., 2013; Suprun, Tokmakov, 2013; Savel'ev et al., 2014a, b; Shamshin, Savelieva, 2014).

Fruit ripening is controlled by internal ethylene concentration that plays an important role in apple softening and is associated with a rapid rise in ethylene production. Ethylene biosynthesis in plants is controlled by two enzymes: 1-aminocyclopropane-1-carboxylate synthase (ACC synthase (ACS) (EC 4.4.1.14)) and 1-aminocyclopropane-1-carboxylate oxidase (ACO (EC 1.14.17.4)) that belong to large gene families. The two most well-studied genes encoding these enzymes in $M$. domestica are Md-ACS1 (LG 15) and Md-ACO1 (LG10) (Sunako et al., 1999; Harada et al., 2000; Oraguzie et al., 2004, 2007; Costa et al., 2005). Two alleles have been identified in the $M d-A C O 1$ locus: the cultivars homozygous for low ethylene allele $1(525 \mathrm{bp}$ ) show better firmness retention than heterozygous cultivars and cultivars homozygous for allele 2 (587 bp) (Costa et al., 2005, 2010; Zhu, Barritt, 2008). Two alleles were also reported for the $M d$ - $A C S 1$ locus (Harada et al., 2000; Oraguzie et al., 2004, 2007; Nybom et al., 2008; Zhu, Barritt, 2008). Allele 2 (655 bp) is associated with a reduced ethylene production while allele 1 (489 bp) results in normal ethylene production. Of these two loci, $M d-A C S 1$ appears to have the strongest effect on fruit storage (Nybom et al., 2013).

Expansins are the proteins involved in disruption of the non-covalent bonds between the hemicellulose matrix and the cellulose microfibril of a cell wall during fruit softening (Costa et al., 2008). A functional marker was developed based on the microsatellite motif within the untranslated region of expansin gene Md-Exp7 (LG1) (Costa et al., 2008). The allelic composition of studied apple cultivars for the SSR marker was associated with differences in fruit softening: $198 \mathrm{bp}$ (best firmness retention), $202 \mathrm{bp}$ (intermediate) and $214 \mathrm{bp}$ (worst) (Costa et al., 2008). Later screening of apple cultivars and species collections revealed some rare $M d$-Exp 7 alleles with unknown effect on fruit softening (Nybom et al., 2012, 2013; Savel'ev et al., 2014b).

These markers were used to study the allelic diversity of the $M d-A C S 1, M d-A C O 1$ and $M d-\operatorname{Exp} 7$ genes in different apple germplasm collections, including modern Russian apple cultivars and other species of genus Malus (Zhu, Barritt, 2008; Nybom et al., 2012, 2013; Suprun, Tokmakov, 2013; Savel'ev et al., 2014a, b; Shamshin, Savelieva, 2014). However, their predictive power had turned out to be rather low (Nybom et al., 2013).

VIR collection of plant genetic resources is one of the most diverse and interesting in the Russian Federation and includes many varieties, forms and species of genus Malus. At Pushkin and Pavlovsk Laboratories of VIR many local apple cultivars from Russia (distributed throughout the country and regional), Eastern and Western Europe, the Baltic countries and Scandinavia are present. This collection had never been previously involved in large-scale studies using DNA markers, although, some of the cultivars are widely used in breeding programs for their ecological plasticity, increased adaptation to abiotic stress and disease resistance, which makes a search for new donors of valuable traits among them a worthy affair.

The aim of this work was to study genetic diversity and allelic configuration of the ethylene and expansin biosynthesis genes (Md-ACS1, Md-ACO1 and Md-Exp7) involved in control of fruit softening in local apple cultivars from the $e x$ situ collection of Pushkin and Pavlovsk Laboratories of VIR.

\section{Materials and methods}

The plant material was obtained from Pushkin and Pavlovsk Laboratories of VIR. The collection comprised 89 accessions, including 87 local apple cultivars and 2 reference cultivars. All the names of the accessions together with their catalogue numbers can be found in Table.

Total genomic DNA was extracted from the fresh leaves using the Qiagen DNeasy Plant Mini Kit following the manufacturers' protocols.

The sequences of the $M d-A C S 1$ and $M d-A C O 1$ primers and the relative PCR conditions were reported by T. Harada et al. (2000) and F. Costa et al. (2005) respectively, and the sequences of the $M d$-Exp 7 SSR primers and the relative PCR conditions were reported by F. Costa et al. (2008): Md-ACO1f 5'-TCCCCCCAATGCACCACTCCA-3'; Md-ACOlr 5'-GATTCCTTGGCCTTCATAGCTTC-3'; MdACSIf 5'-AGAGAGATGCCATTTTTGTTCGTAC-3'; MdACSlr 5'-CCTACAAACTTGCGTGGGGATTATAAGTGT-3'; Md-Exp7f 5'-(Fam) CATAGAAGGTGGCATGAGCA-3'; Md-Exp-7r 5'-TTTCTCCTCACACCCAAACC-3'.

PCR reactions were performed in T100 Thermal Cycler (BioRad) in a final mix of $15 \mu$ containing $20 \mathrm{ng}$ of genomic DNA, $0.25 \mathrm{mM}$ of each dNTP, $2.5 \mathrm{mM} \mathrm{MgCl}_{2}, 0.2 \mu \mathrm{M}$ of each primer, $1 \mathrm{U}$ of Taq polymerase and $1.5 \mu \mathrm{l}$ of $10 \mathrm{x}$ PCR-buffer (all components produced by Dialat (Russia)), using the allele specific primers manufactured by Evrogen (Russia).

The PCR products with $M d-A C S 1$ and $M d-A C O 1$ primers were separated on a $2 \%$ agarose gel, stained with ethidium bromide and evaluated on a UV-light box, using GeneRuler 100 bp Plus DNA Ladder (Thermo Fisher Scientific).

$M d$-Exp 7 SSR analysis of labeled amplification products was performed by capillary electrophoresis on ABI Prism 3130xl Genetic Analyzer, (Thermo Fisher Scientific). The results were analyzed using GeneMapper v4.1 (Thermo Fisher Scientific).

\section{Results}

For all the studied accessions, stable, clearly reproducible results were obtained from the three markers, and reference cultivars with known $M d-A C S 1, M d-A C O 1$ and $M d-\operatorname{Exp} 7$ 
Analyzed apple cultivars

\begin{tabular}{|c|c|c|c|c|c|}
\hline \multirow[t]{2}{*}{ Local cultivars } & \multirow{2}{*}{$\begin{array}{l}\text { Catalogue } \\
\text { number }\end{array}$} & \multirow{2}{*}{$\begin{array}{l}\text { Maturation } \\
\text { time* }\end{array}$} & \multicolumn{3}{|c|}{ Allelic configuration } \\
\hline & & & ACS1 & ACO1 & EXP7 \\
\hline Anis Seryj & 43 & A & $1 / 1$ & $1 / 2$ & $198: 202$ \\
\hline Anis Shaczkij & 15358 & A & $1 / 1$ & $1 / 2$ & 202 \\
\hline Anisovka & 47 & A & $1 / 2$ & $1 / 2$ & 198 \\
\hline Antonovka Monastyrskaya & 68 & A & $1 / 1$ & $1 / 2$ & $198: 202$ \\
\hline Antonovka Obyknovennaya & 74 & W & $1 / 1$ & $1 / 2$ & $198: 202$ \\
\hline Antonovka Obyknovennaya & 21190 & W & $1 / 1$ & $1 / 2$ & $198: 202$ \\
\hline Antonovka Obyknovennaya & 711 & W & $1 / 1$ & $1 / 2$ & $198: 202$ \\
\hline Antonovka Rzhavaya & 31709 & W & $1 / 1$ & $1 / 2$ & $198: 202$ \\
\hline Arkad Krasnyj & 31708 & $\mathrm{~S}$ & $1 / 1$ & $1 / 2$ & 202 \\
\hline Arkad Letnij Zheltyj & 140 & $\mathrm{~S}$ & $1 / 1$ & $1 / 2$ & $198: 202$ \\
\hline Ahlebina Pozdnee & 25247 & A & $1 / 1$ & $1 / 2$ & 202 \\
\hline Bashkirskij Krasavec & 185 & $S$ & $1 / 1$ & $1 / 2$ & 198:202 \\
\hline Beloe Osennee ot Ryzhego & 23976 & A & $1 / 1$ & $1 / 2$ & 198 \\
\hline Naliv Belyj & 1011 & $S$ & $1 / 1$ & $1 / 2$ & $198: 202$ \\
\hline Bel'Chernyshevskaya & 25211 & A & $1 / 1$ & $1 / 2$ & $198: 202$ \\
\hline Berezovka ot Isakova & 24476 & A & $1 / 2$ & $1 / 2$ & $198: 210$ \\
\hline Borovinka & 276 & A & $1 / 1$ & $1 / 2$ & $202: 210$ \\
\hline Borovinka Akulovskaya & 38174 & A & $1 / 1$ & $1 / 2$ & $198: 202$ \\
\hline Borovinka Ivancovskaya & 24781 & A & $1 / 1$ & $1 / 2$ & $198: 202$ \\
\hline Borovinka Moguchaya & 25230 & A & $1 / 1$ & $1 / 2$ & $198: 202$ \\
\hline Buhovka & 38211 & A & $1 / 1$ & $1 / 2$ & 198:202 \\
\hline Vargul' $^{\prime}$ & 350 & A & $1 / 1$ & $1 / 2$ & 202 \\
\hline Vinnoe & 375 & $\mathrm{~S}$ & $1 / 1$ & $1 / 2$ & $198: 202$ \\
\hline Voskovoe Prevoshodnoe & 20343 & W & $1 / 1$ & $1 / 2$ & $198: 202$ \\
\hline Voskovoe Stepino & 31711 & A & $1 / 1$ & $1 / 2$ & 198:202 \\
\hline Vydubeckaya Plakuchaya & 31722 & W & $1 / 1$ & $1 / 2$ & 198 \\
\hline Golubok Kryugera & 12247 & A & $1 / 1$ & $1 / 2$ & $198: 202$ \\
\hline Gravenshtejnskoe Russkoe & 444 & $\mathrm{~S}$ & $1 / 1$ & $1 / 2$ & $198: 202$ \\
\hline Grushovka Grebnickogo & 20284 & $\mathrm{~S}$ & $1 / 1$ & $1 / 2$ & $198: 206$ \\
\hline Grushovka Revel'skaya & 10128 & A & $1 / 1$ & $1 / 2$ & 198:202 \\
\hline Grushovka Yudicheva & 24484 & A & $1 / 1$ & $1 / 2$ & 202 \\
\hline Delyukinskoe & 24470 & A & $1 / 1$ & $1 / 2$ & 198 \\
\hline Dynnoe & 566 & $\mathrm{~S}$ & $1 / 1$ & $1 / 2$ & 198:202 \\
\hline Zelenoe Knyazheskoe & 25259 & W & $1 / 1$ & $1 / 2$ & $198: 202$ \\
\hline Zimnee ot Berdashkevicha & 25234 & W & $1 / 1$ & $1 / 2$ & 202 \\
\hline Zimnee Uchkhozovskoe & 23975 & W & $1 / 1$ & $1 / 2$ & $202: 210$ \\
\hline Kal'vil'Belyj Letnij & 658 & $\mathrm{~S}$ & $1 / 1$ & $1 / 2$ & 198 \\
\hline Kal'vil' Oranzhevyj & 10134 & A & $1 / 1$ & $1 / 2$ & 198:202 \\
\hline Korichnoe Ananasnoe & 29 & A & $1 / 1$ & $1 / 2$ & 198:202 \\
\hline Korichnoe Beloe & 25257 & A & $1 / 1$ & $1 / 2$ & 198 \\
\hline Korichnoe Polosatoe & 805 & A & $1 / 1$ & $1 / 2$ & $198: 202$ \\
\hline Korobovka & 811 & $\mathrm{~S}$ & $1 / 1$ & $1 / 2$ & 202 \\
\hline Korobovka Novaya & 31726 & A & $1 / 1$ & $1 / 2$ & 202 \\
\hline Korolevskoe & 21188 & A & $1 / 1$ & $1 / 2$ & $198: 202$ \\
\hline Lavia & 21179 & $S$ & $1 / 1$ & $1 / 2$ & 198 \\
\hline
\end{tabular}




\section{End of Table}

\begin{tabular}{|c|c|c|c|c|c|}
\hline \multirow[t]{2}{*}{ Local cultivars } & \multirow{2}{*}{$\begin{array}{l}\text { Catalogue } \\
\text { number }\end{array}$} & \multirow{2}{*}{$\begin{array}{l}\text { Maturation } \\
\text { time }\end{array}$} & \multicolumn{3}{|c|}{ Allelic configuration } \\
\hline & & & ACS1 & ACO1 & EXP7 \\
\hline Lajzanskoe Zimnee & 20333 & W & $1 / 1$ & $1 / 2$ & 202 \\
\hline Letnee Rannee & 25222 & $\mathrm{~S}$ & $1 / 1$ & $1 / 2$ & 198:202 \\
\hline Limonovka & 24782 & $A$ & $1 / 1$ & $1 / 2$ & $198: 202$ \\
\hline Litovskoe Saharnoe & 15391 & $\mathrm{~S}$ & $1 / 1$ & $1 / 2$ & 198:202 \\
\hline Majskoe ot Ryzhego & 23973 & A & $1 / 1$ & $1 / 2$ & $198: 202$ \\
\hline Mamutovskoe & 15354 & A & $1 / 1$ & $1 / 2$ & $202: 210$ \\
\hline Medovoe ot Verevkina & 20275 & $\mathrm{~S}$ & $1 / 1$ & $1 / 2$ & 198 \\
\hline Mestnoe Lezhkoe & 20281 & W & $1 / 2$ & $1 / 2$ & $202: 210$ \\
\hline Naliv Dymchatyj & 24773 & $\mathrm{~S}$ & $1 / 1$ & $1 / 2$ & 202 \\
\hline Nalivnoe Yantarnoe & 1025 & $\mathrm{~S}$ & $1 / 1$ & $1 / 2$ & 198:202 \\
\hline Novgorodchina & 25217 & $S$ & $1 / 1$ & $1 / 2$ & 202 \\
\hline Osennee Polosatoe & 1083 & A & $1 / 1$ & $1 / 2$ & 198:202 \\
\hline Osennij Kvas & 25255 & A & $1 / 1$ & $1 / 2$ & 198 \\
\hline Pajdeskoe Zimnee & 1112 & A & $1 / 1$ & $1 / 2$ & 198 \\
\hline Papirovka & 38223 & $\mathrm{~S}$ & $1 / 1$ & $1 / 2$ & 202 \\
\hline Pestrushka & 24774 & $\mathrm{~S}$ & $1 / 1$ & $1 / 2$ & 202 \\
\hline Plodovitka Rannyaya & 1216 & $\mathrm{~S}$ & $1 / 1$ & $1 / 2$ & 198:202 \\
\hline Ponyavinskoe & 1233 & W & $1 / 1$ & $1 / 2$ & 198:202 \\
\hline Putivka & 25233 & $A$ & $1 / 1$ & $1 / 2$ & $198: 212$ \\
\hline Pyl'tsamaaskoe Zimnee & 20309 & W & $1 / 1$ & $1 / 2$ & 198:202 \\
\hline Rannyaya Pytalova & 25254 & $\mathrm{~S}$ & $1 / 1$ & $1 / 2$ & $198: 202$ \\
\hline Raspisnoe & 10126 & $S$ & $1 / 1$ & $1 / 2$ & $198: 206$ \\
\hline Rozovka & 21194 & $S$ & $1 / 1$ & $1 / 2$ & $198: 202$ \\
\hline Rozovka ot Ryzhego & 23972 & $\mathrm{~S}$ & $1 / 1$ & $1 / 2$ & 202 \\
\hline Severnyj Velikan & 1503 & W & $1 / 1$ & $1 / 2$ & $206: 210$ \\
\hline Seyanec Trebu & 433 & A & $1 / 1$ & $1 / 2$ & $198: 202$ \\
\hline Sladkoe Zimnee & 21195 & W & $1 / 1$ & $1 / 2$ & 202 \\
\hline Slivochnoe & 1573 & A & $1 / 1$ & $1 / 2$ & 198:202 \\
\hline Sujslepskoe & 1626 & $\mathrm{~S}$ & $1 / 1$ & $1 / 2$ & 202 \\
\hline Tellisaare & 1654 & W & $1 / 1$ & $1 / 2$ & $202: 210$ \\
\hline Terent'evka & 12309 & A & $1 / 1$ & $1 / 2$ & 202 \\
\hline Titovka & 1667 & A & $1 / 1$ & $1 / 2$ & 202 \\
\hline Titovka klon & 21196 & A & $1 / 1$ & $1 / 2$ & 198:202 \\
\hline Tyushkinskoe Krasnoe & 10133 & A & $1 / 1$ & $1 / 2$ & $198: 202$ \\
\hline Fedorovskoe & 24489 & A & $1 / 1$ & $1 / 2$ & $198: 210$ \\
\hline Chernoguz & 14495 & A & $1 / 1$ & $1 / 2$ & 198 \\
\hline Chernoe Derevo & 1766 & W & $1 / 1$ & $1 / 2$ & $198: 202$ \\
\hline Chulanovka & 1774 & $\mathrm{~S}$ & $1 / 1$ & $1 / 2$ & $198: 202$ \\
\hline Shelkovka & 1809 & $\mathrm{~S}$ & $1 / 1$ & $1 / 2$ & $202: 206$ \\
\hline Shtrejfling Krasnyj & 25196 & A & $1 / 1$ & $1 / 2$ & 202 \\
\hline Yablonya Dobrynicheva & 24487 & A & $1 / 1$ & $1 / 2$ & $198: 202$ \\
\hline Yalkarnan Kesa & 20311 & $\mathrm{~S}$ & $1 / 1$ & $1 / 2$ & $202: 210$ \\
\hline & & Reference $\mathrm{Cl}$ & & & \\
\hline Fuji & & & $2 / 2$ & $1 / 1$ & 202 \\
\hline Granny Smith & & & $1 / 2$ & $1 / 2$ & 198:202 \\
\hline
\end{tabular}

*S-summer; A - autumn; W - winter. 


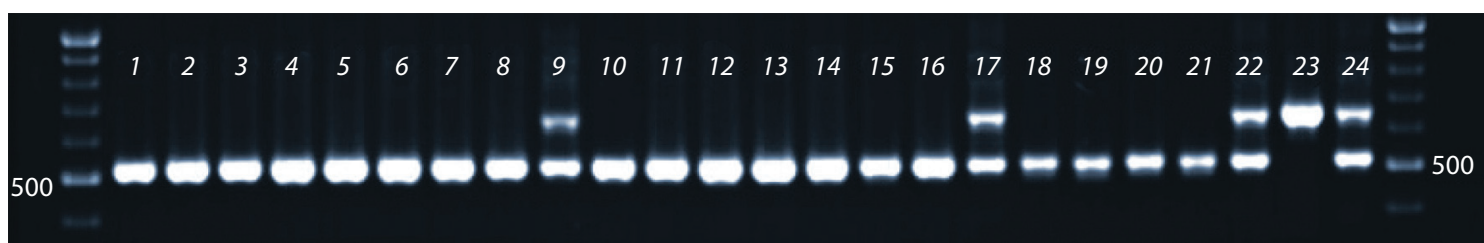

$b$

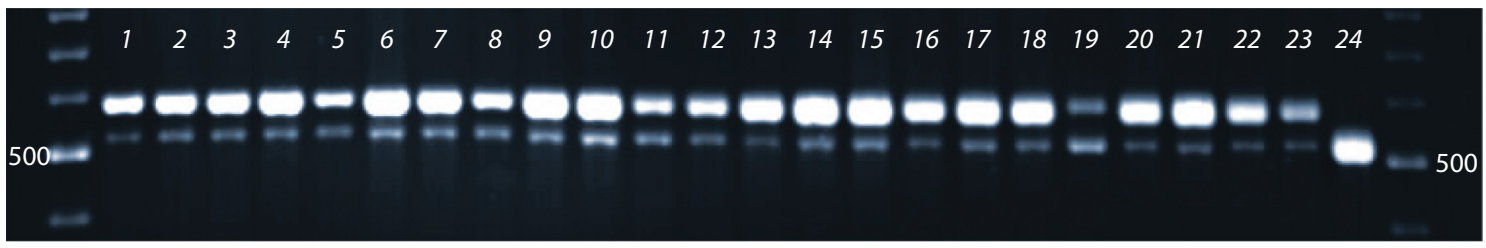

Md-ACS1 (a) and Md-ACO1 (b) polymorphisms detected in the studied local apple cultivars.

a: 1 - Anis Seryi; 2 - Anis Ahaczkij; 3 - Vargul'; 4 - Vinnoe; 5 - Voskovoe Prevoshodnoe; 6 - Voskovoe Stepino; 7 - Vydubeckaya Plakuchaya; 8 - Gravenshtejnskoe Russkoe; 9 - Anisovka; 10 - Grushovka Grebnickogo; 11 - Grushovka Revel'skaya; 12 - Grushovka Yudicheva; 13 - Delyukinskoe; 14 - Dynnoe; 15 - Zelenoe Knyazheskoe; 16 - Zimnee Uchkhozovskoe; 17 - Berezovka ot Isakova; 18 - Kal'vil' Belyj Letnij; 19 - Kal'vil' Oranzhevyj; 20 - Korichnoe Ananasnoe; 21 - Korichnoe Beloe; 22 - Mestnoe Lezkoe; 23 - Fuji; 24 - Granny Smith.

b: 1 - Borovinka Moguchaya; 2 - Buhovka; 3 - Vargul'; 4 - Vinnoe; 5 - Voskovoe Prevoshodnoe; 6 - Voskovoe Stepino; 7 - Vydubeckaya Plakuchaya; 8 - Golubok Kryugera; 9 - Gravenshtejnskoe Russkoe; 10 - Grushovka Grebnickogo; 11 - Grushovka Revel'skaya; 12 - Grushovka Yudicheva; 13 - Delyukinskoe; 14 - Dynnoe; 15 - Zelenoe Knyazheskoe; 16 - Zimnee ot Berdashkevicha; 17 - Zimnee Uchkhozovskoe; 18 - Kal'vil' Belyj Letnij; 19 - Kal'vil' Oranzhevyj; 20 - Korichnoe Ananasnoe; 21 - Korichnoe Beloe; 22 - Korichnoe Polosatoe; 23 - Granny Smith; 24 - Fuji.

genotypes were used to confirm the results (see Table, Figure, $a$ and $b$ ).

Md-ACS1 and Md-ACO1 loci. Analysis of the $M d-A C S 1$ locus polymorphism of 87 local apple cultivars from the collection allowed to identify two known alleles: $M d-A C S 1-1$ (489 bp) and $M d-A C S 1-2$ (655 bp). Eighty four samples were homozygous for the $M d-A C S 1-1$ allele, while only three samples - Anisovka (47), Berezovka ot Isakova (24476) and Mestnoe Lezhkoe (20281) - were heterozygous for this locus (see Figure, $a$ ). Among the samples studied, no homozygotes for the $M d$-ACS1-2 allele were found.

All the studied local cultivars were heterozygous for the $M d-A C O 1$ locus and carried alleles $M d-A C O 1-1$ (525 bp) and $M d-A C O 1-2$ (587 bp) (see Figure, $b$ ). No homozygous samples were identified from these alleles.

Md-Exp7 locus. Microsatellite marker Md-Exp7 allowed to identify five alleles in the studied samples $(198,202,206$, 210, 212). Alleles 198 and 202 bp were the most common in the studied cultivars. In 44 local cultivars a combination of 198:202 alleles was detected, 19 local cultivars were homozygous for allele 202, 11 local cultivars - for allele 198 provided that the studied samples do not have any undetected allele. The presence of three rare alleles $(206,210,212 \mathrm{bp})$ was detected in 13 local cultivars studied. So, allele 210 was identified in nine local cultivars, allele 206 - in four, and allele 212 - in one cultivar (see Table).

\section{Discussion}

Md-ACS1 and $\boldsymbol{M d - A C O 1}$ loci. In our study of 87 lokal apple cultivars from the collection of Pushkin and Pavlovsk Laboratories of VIR the $M d-A C S 1$ allele 2, associated with low ethylene production, was very rare. We identified only three heterozygous genotypes $M d-A C S 1-1 / 2$ (Anisovka, Berezovka ot Isakova and Mestnoe Lezkoe), while the remaining 84 local cultivars were homozygous for allele 1 (see Table).

In the previous screening of old and modern apple cultivars collection, out of 127 studied cultivars only eight were homo- zygous for $M d$-ACS1 allele 2, while 46 cultivars were heterozygous and 73 - homozygous for allele 1 (Nybom et al., 2013). In contrast, of 60 cultivars/selections from Washington State University apple breeding program, 28 were homozygous for allele 2, 27 were heterozygous, and 5 - homozygous for allele 1 (Zhu, Barritt, 2008).

The results reported for 48 modern Russian apple cultivars showed that 19 cultivars were heterozygous for the $M d$ - $A C S 1$ locus, and 17 and 8 cultivars were homozygous for alleles 1 and 2 respectively (Suprun, Tokmakov, 2013). Among 72 apple cultivars from the collection of Michurin All-Russian Research Institute of Genetics and Breeding of Fruit Crops only nine Russian cultivars had the $M d-A C S 1-1 / 2$ genotype and no homozygotes for allele 2 were detected (Savel'ev et al., 2014a).

It was reported that relative frequencies of the two $M d$ ACS1 alleles varied depending on time of introduction of apple cultivars and the frequency of desirable allele 2 had increased in modern apple cultivars, indicating that this allele has been favored by selection for improved fruit quality in modern apple breeding programs (Nybom et al., 2008, 2012). At the same time, later statistical evaluation did not reveal any effect of cultivar age on fruit softening (Nybom et al., 2013).

Our data have confirmed that $M d-A C S 1-2$ allele frequency is low in old local apple cultivars and is increasing not only in foreign apple cultivars, but also in modern Russian apple cultivars, which may be due to a wider involvement of foreign material in the breeding process.

All the studied 87 local apple cultivars were heterozygous for $M d$-ACO1 locus (see Figure, $b$ ). Similar results were reported for 48 modern Russian apple cultivars (Suprun, Tokmakov, 2013) and 72 apple cultivars from the collection of Michurin All-Russian Research Institute of Genetics and Breeding of Fruit Crops (Savel'ev et al., 2014a). As well as among the 95 studied cultivars and selections used as parents in Washington State University apple breeding program 76 were also heterozygous for $M d-A C O 1$ (Zhu, Barritt, 2008). 
It was suggested that selection for fruit firmness has had little impact on increasing the frequency of low ethylene producing ACO1-1 homozygotes in apple breeding programs (Zhu, Barritt, 2008). At the same time in the study of 127 old and modern apple cultivars, the majority was homozygous for undesirable allele $M d-A C O 1-2$, and the study showed no significant variation in softening rate during storage among the cultivars with different allele configurations (Nybom et al., 2013).

$M d-A C S 1$ and $M d-A C O 1$ allelic diversity was also studied in 35 samples of genus Malus representing sections Docyniopsis, Chloromeles, Gymnomeles and Malus (Shamshin, Savelieva, 2014). Allele 2 of the $M d$-ACS1 gene, associated with reduced level of ethylene synthesis, was identified only in two species: M. prunifolia (K2454) and M. silvestris (K41639), the latter was homozygous for allele 2. Of the 35 studied genotypes, 22 were heterozygous and 12 were homozygous for the Md-ACO1-1 allele (Shamshin, Savelieva, 2014).

Md-Exp7 locus. Among the three common Md-Exp7 alleles (198, 202 and 214 bp) described by F. Costa et al. (2008), in our study we did not find allele $214 \mathrm{bp}$, but identified three additional alleles - 206, 210 and $212 \mathrm{bp}$. The most common genotype was 198:202 found in 44 local cultivars, while 19 were homozygous for allele 202 and 11 - for allele 198 provided that they really were homozygous and did not carry an undetected allele (see Table). Moreover, 13 local cultivars had three rare alleles. Allele 210 was found in nine genotypes, allele 206 - in four and allele 212 - in one genotype, while cultivar Severnyj Velikan was heterozygous for rare alleles 206:210 (see Table).

The uncommon alleles were previously described in several studies. H. Nybom et al. (2012, 2013) found the same common alleles, and additional alleles at lower frequencies: 196, 200, 206, 208, 210, 212, 216 and $220 \mathrm{bp}$. It should be noted that alleles 204, 210, 220, 226 and 230 bp were also detected in wild species of genus Malus (Savel'ev et al., 2014b). Since there have been no data on the effect of these alleles on fruit softening, their role remains uncertain and requires further study.

In the study by H. Nybom et al. $(2012,2013)$ of $M d-\operatorname{Exp} 7$ locus polymorphism in a large apple collection the most common genotype was 202:202 and genotype 198:202 was also quite common. It was shown that allele 202 frequency is increasing in modern apple cultivars, suggesting that this marker has been favored by selection in modern apple breeding programs and therefore is more likely to be associated with low softening (Nybom et al., 2012). It was also reported that the cultivars homozygous for marker 202 showed a significantly lower softening compared to heterozygous cultivars (198:202) (Nybom et al., 2013).

In our study among 87 local cultivars the 198:202 genotype was the most common. We did not find association between early-maturing and late-maturing cultivars and the $M d-\operatorname{Exp} 7$ genotype (see Table). In previously studied Russian apple cultivars collection the most common were genotypes homozygous for allele 202 and 198:202 genotypes (Savel'ev et al., 2014a). At the same time, analysis of $M d-\operatorname{Exp} 7$ locus polymorphism in the Malus species representing four sections of the genus, showed that allele 202 was the most common and the authors suggested that this allele was the oldest one, while in species of section Malus that includes M. domestica, the most common were alleles 198, 202 and 204 bp (Savel'ev et al., 2014b).

Thus, the allelic diversity of the ethylene (Md-ACS1, $M d$ $A C O 1)$ and expansin (Md-Exp7) biosynthesis genes has been evaluated for the first time in the collection of local apple cultivars from Pushkin and Pavlovsk Laboratories of VIR. The allele frequencies in the collection generally coincide with the data of previous studies. The $M d-A C S 1$ allele 2 frequency is low in old local apple cultivars and is increasing in modern apple cultivars, while all the studied local cultivars are heterozygous for $M d-A C O 1$ locus, as well as most modern Russian apple cultivars. Half of the studied local cultivars are heterozygous for $M d-\operatorname{Exp} 7$ (198:202). No association has been found between the $M d-\operatorname{Exp} 7$ genotype and the maturation time of the cultivars. The obtained results can be used for additional evaluation of the local apple cultivars potential for breeding.

\section{Acknowledgements}

This work was supported by the Russian Foundation for Basic Research, Project No. 17-29-08020, the plant material for this study was provided by Pushkin and Pavlovsk Laboratories of VIR under State contract No. AAAA-A17-117030910078-3.

\section{Conflict of interest}

The authors declare no conflict of interest.

\section{References}

Bratilova N.P., Moksina N.V., Gerasimova O.A., Chepelev N.L. Stages of picking and storage for different cultivars of apple fruit in the Botanical garden named after V.M. Krutovsky. The Bulletin of KrasGAU. 2015;11:146-150.

Costa F., Peace C.P., Stella S., Serra S., Musacchi S., Bazzani M., Sansavini S., Van de Weg W.E. QTL dynamics for fruit firmness and softening around an ethylene-dependent polygalacturonase gene in apple (Malus $\times$ domestica Borkh.). J. Expt. Bot. 2010;61(11):30293039. DOI 10.1093/jxb/erq130.

Costa F., Stella S., Van de Weg W.E., Guerra W., Cecchinel M., Dallavia J., Koller B., Sansavini S. Role of the genes $\mathrm{Md}-\mathrm{ACOl}$ and $\mathrm{Md}$ ACSl in ethylene production and shelf life of apple (Malus domestica Borkh.). Euphytica. 2005;141:181-190. DOI 10.1007/s10681-0056805-4.

Costa F., Van de Weg W.E., Stella S., Dondini L., Pratesi D., Musacchi S., Sansavini S. Map position and functional allelic diversity of $M d-\operatorname{Exp} 7$, a new putative expansin gene associated with fruit softening in apple (Malus $\times$ domestica Borkh.) and pear (Pyrus communis). Tree Genet. Genomes. 2008;4:575-586. DOI 10.1007/s11295-0080133-5.

Harada T., Sunako T., Wakasa Y., Soejima J., Satoh T., Niizeki M. An allele of 1-aminocyclopropane-1-carboxylate synthase gene ( $M d$ $A C S 1)$ accounts for the low ethylene production in climacteric fruits of some apple cultivars. Theor. Appl. Genet. 2000;101:742-746. DOI $10.1007 / \mathrm{s} 001220051539$.

Nybom H., Ahmadi-Afzadi M., Garkava-Gustavsson L., Sehic J., Tahir I. Selection for improved fruit texture and storability in apple. Acta Hort. 2012;934(2):849-854. DOI 10.17660/ActaHortic.2012. 934.112.

Nybom H., Ahmadi-Afzadi M., Sehic J., Hertog M. DNA marker-assisted evaluation of fruit firmness at harvest and post-harvest fruit softening in a diverse apple germplasm. Tree Genet. Genomes. 2013;9:279-290. DOI 10.1007/s11295-012-0554-z.

Nybom H., Sehic J., Garkava-Gustavsson L. Modern apple breeding is associated with a significant change in allelic ratio of the ethylene production gene Md-ACS1. J. Hortic. Sci. Biotechnol. 2008;83:673677. DOI 10.1080/14620316.2008.11512442. 
Oraguzie N.C., Iwanami H., Soejima J., Harada T., Hall A. Inheritance of $M d-A C S 1$ gene and its relationship to fruit softening in apple ( $M a-$ lus $\times$ domestica Borkh.). Theor. Appl. Genet. 2004;108:1526-1533. DOI 10.1007/s00122-003-1574-8.

Oraguzie N.C., Volz R.K., Whitworth C.J., Bassett H.C.M., Hall A.J., Gardiner S. Influence of $M d-A C S 1$ allelotype and harvest season within an apple germplasm collection on fruit softening during cold air storage. Postharvest Biol. Technol. 2007;44:212-219. DOI 10.1016/j.postharvbio.2006.12.013.

Savel'ev N.I., Shamshin I.N., Kudryavtzev A.M. Apples for the alleles of genes of shelf life and quality of fruits. Reports of the Russian Academy of Agricultural Sciences. 2014a;3:17-20.

Savel'ev N.I., Shamshin I.N., Savel'eva N.N., Lyzhin A.S. Polymorphism for the $M D-E X P-7$ gene for expansin biosynthesis in wild species of the genus Malus Mill. Vavilovskii Zhurnal Genetiki i Selektsii = Vavilov Journal of Genetics and Breeding. 2014b;18(4/1): 713-717.

\section{ORCID ID}

I.N. Shamshin orcid.org/0000-0002-4464-1876

A.V. Shlyavas orcid.org/0000-0002-8009-6780

A.A. Trifonova orcid.org/ 0000-0001-9618-5932

K.V. Boris orcid.org/0000-0002-8479-4949

A.M. Kudryavtsev orcid.org/0000-0001-6029-0730
Shamshin I.N., Savelieva N.N. Identifying the gene sources for ethylene biosynthesis ( $M D-A C S 1$ and $M D-A C O 1)$ in genoplasm of wild apple tree species of the genus Malus (L.) Mill. Herald of the Russian Academy of Agricultural Sciences. 2014;4:35-37.

Sunako T., Sakuraba W., Senda M., Akada S., Ishikawa R., Niizeki M., Harada T. An allele of the ripening-specific 1-amino-cyclopropane1-carboxylic acid synthase $(A C S 1)$ in apple fruit with a long storage life. Plant Physiol. 1999;119(4):1297-1304. DOI 10.1104/pp.119.4. 1297.

Suprun I.I., Tokmakov S.V. Allelic diversity of ethylene biosynthesis related $M D-A C S 1$ and $M D-A C O 1$ genes in Russian apple germplasm. Vavilovskii Zhurnal Genetiki i Selektsii $=$ Vavilov Journal of Genetics and Breeding. 2013;17(23):298-302.

Zhu Y., Barritt B.H. $M d-A C S 1$ and $M d-A C O 1$ genotyping of apple (Malus $\times$ domestica Borkh.) breeding parents and suitability for marker-assisted selection. Tree Genet. Genomes. 2008;4:555-562. DOI 10.1007/s11295-007-0131-z. 